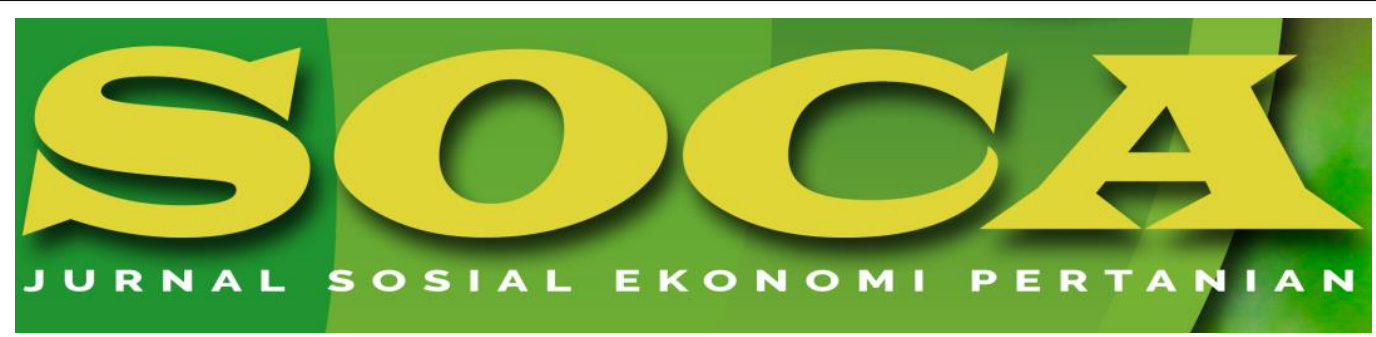

https://ojs.unud.ac.id/index.php/soca

\title{
Socio-Economic Studies in Beef Cattle and Corn Crop Business
}

\author{
Supardi Rusdiana and Angga Ardhati Rani Hapsari \\ Animal Research Center Ciawi-Bogor Po.Box.221 Bogor-West Java, Indonesia \\ Email: s.rusdiana20@gmail.com \\ Mobile: 081282010532
}

Submitted: March 19th, 2020; Revised: April 21st, 2020; Accepted: May 12th, 2020

\begin{tabular}{|c|c|}
\hline & Abstract \\
\hline Keywords: & The purpose of this research was to analyze the economic value of \\
\hline Socio- & farmers in beef cattle business and corn crop business. The research \\
\hline Economic; & was conducted in Pallangga Village, Pallangga Sub-District, Gowa \\
\hline Business; & Regency, South Sulawesi in 2018. The research used a survey \\
\hline Cow; Corn; & method and interviews with 26 farmers. The research method used \\
\hline Farmer & a statistical analysis of $t$-test and economic value of $R / C$. Primary \\
\hline & and secondary data were analyzed descriptively, quantitatively and \\
\hline & $\begin{array}{l}\text { economic analysis. The results showed that the results of the t-test } \\
\text { analysis of the average similarity at } 99 \% \text { confidence level, there was }\end{array}$ \\
\hline & a significant difference between the number of beef cattle and land \\
\hline & $\begin{array}{l}\text { area, a significance of } 0,000 \text { smaller }(P<0.05) \text {. Farmer education had } \\
\text { no significant effect on the } 95 \% \text { confidence level, because it was }\end{array}$ \\
\hline & supported by the experience of farmers which was quite high \\
\hline & and had a positive effect on beef cattle and corn plant. It was \\
\hline & $\begin{array}{l}\text { supported by the age of farmers who were still productive, so farmers } \\
\text { were able to increase working time. Net profit from beef cattle }\end{array}$ \\
\hline & business was Rp.4.85 million/year, equivalent to \\
\hline & Rp.404,166/month with $R / C$ of 1.92 . The net profit from corn crop \\
\hline & business was Rp.5.88 million/year, equivalent to \\
\hline & $\begin{array}{l}R p .404,166 / \text { month with } R / C \text { of } 1.97 \text {. These results indicated the } t \text { - } \\
\text { test value as a variable that significantly affected }(P>0.05) \text {. In terms }\end{array}$ \\
\hline & of economic value, beef cattle and corn crop business in farmers with \\
\hline & $\begin{array}{l}\text { an } R / C \text { value }>1 \text {, it can be said that the business was feasible to be } \\
\text { maintained. }\end{array}$ \\
\hline
\end{tabular}


How to Cite (APA 6 ${ }^{\text {th }}$ Style):

Rusdiana, S., \& Hapsari, A. A. R. (2020). Socio-Economic Studies in Beef Cattle and Corn Crop Business. SOCA: Jurnal Sosial Ekonomi Pertanian, 14(3), 521-530. https://doi.org/https://doi.org/10.24843/SOCA.2020.v14.i03.p13

\section{INTRODUCTION}

Based on the environment and habitat, socially, economically and culturally, the people in Gowa Regency, aside from did agricultural business was also did beef cattle business. Where, the business pattern was diversified between food crop and beef cattle. Beef cattle business and corn crop business have long been cultivated by farmers in Gowa Regency. In addition, corn straw was widely used by farmers as a daily staple feed for livestock. Almost all farmers own agricultural land, land used for food crops such as rice, corn, peanuts, vegetables and other crops. Land that cultivated or cultivated for farming, rainfed land farmers, irrigated land. Farmers have been able to anticipate the feed needs for beef cattle as well as for the daily economy of farmers. According to Rusdiana et al., (2017) to meet the needs of beef cattle besides fulfilled from corn crop waste, farmers look forage feed around the residential neighborhood or other locations. This means that farmers can reduce the cost of production for beef cattle feed that can be fulfilled from corn straw waste.

Beef cattle and food crop businesses have been performed by many small farmers in rural areas. But in reality in the field, beef cattle business in farmers has not yet led to commercial businesses, only limited to side businesses and savings (Rusdiana et al., 2016). According to Sodiq and Yuwono (2016) one of the very important factors in the beef cattle business was the persistence of farmers in conducting their business. Farmers in the agricultural business and beef cattle besides to meet the economic needs of farmers, also the main business of farmers was farming and raising livestock. To produce productivity in beef cattle business, it must be accompanied by regulated breeding selection and a good quality feeding, it will produce high livestock productivity (Bamualim, 2010). Beef cattle livestock business was mostly performed intensively and semi-intensive, beef cattle had the feature as annual income. Various levels of beef cattle and agriculture can be directed at diversification business, so that farmers got optimal profits.

Farmers in the supply of beef cattle feed was quite guaranteed, because almost all farmers cultivated corn crop. According to Yusdja and Ilham (2004) that by providing facilities and infrastructure for the development of agricultural business and livestock business was a strategic step in developing the economy of farmers. It is common and cannot be separated from the fact that, farmers have not been able to provide efficient and good quality feed for the productivity of beef cattle (Rusdiana et al., 2017). So it was necessary to restructure the beef cattle business and corn crop business that can support the improvement of the farmers' economy. Further explained by Prawiradiputra (2009) and Dimitria et al., (2006) efforts to increase the added-value of farmers by providing agricultural land, as a place to produce forage livestock feed (HMT) and human resource support as the main role. The strategy needed to increase beef cattle business and corn crop business through capital and seed supply to farmers.

Then each farmer can be directed towards increasing the capacity of the independent businesses. So that farmers' business was more feasible, and guaranteed the selling price of beef cattle and corn production. The same thing was stated by 
Diwyanto et al., (2002) and Andri (2014) to increase the farmers' income, the business needed to be directed through business training and escort in a sustainable manner. Beef cattle management that based on the local feed technology innovation from corn straw waste was in an integrated and environmentally friendly manner. Local food that was available and used as beef cattle feed was very economical, effective and efficient and can economically reduce production costs (Rusdiana et al., 2010) and (Rusdiana and Soeharsono, 2017). It needed institutional empowerment of farmers who were able to manage their business together with its members, so that the beef cattle business running smoothly. To facilitate the beef cattle business, both in breeding and enlargement, it was necessary to strengthen the business cooperation network (Anantanyu 2011) and (Rusdiana and Adawiyah 2013). Business cooperation was very good if the institutional support of farmers can be performed both horizontally and vertically will be stronger.

For the success of beef cattle business can be determined with the support of strategic policies, the purpose was to increase the beef cattle population and also increase the economic value of farmers (Sodiq et al., 2017). The provision of beef cattle feed that suitable to their needs will increase livestock productivity and increase economic value (Hermawan et al., 2012). Streamline the production cost of beef cattle business and corn crop business, so that farmers got the appropriate economic value of profits. The side products of corn crop, both in the form of leaves and cornhusk, there was a small part left or not used as animal feed (Rusdiana et al., 2019). According to Muzayyanah et al., (2016) that agriculture and livestock business can be managed well, beside to meet economic needs as well as for consumption. Based on the aforementioned problems, the beef cattle business and corn crop business, farmers was limited as side businesses and not directed to commercial businesses, so that the profits of farmers were not yet optimal. The farmers never calculate the cost of production in the beef cattle business or the corn crop business, so the value of farmers' profits cannot be known. The aim of this research was to analyze the economic value of farmers in beef cattle business and corn crop business, so this research needs to be performed.

\section{RESEARCH METHODS \\ Research Location and Time}

The research was conducted in Pallangga Village, Pallangga Sub-District, Gowa Regency, South Sulawesi in 2018. The research used a survey method by interviewing 26 farmers by filling out a list of questions that had been prepared. Primary data obtained from interviews with farmers, which referred to the questionnaire. Whereas secondary data was obtained from the Department of Agriculture and Animal Health of Gowa Regency, information related to the title of the research, ideas of own thought and supported from research results both in journals and proceedings.

\section{Data Analysis}

Primary data were obtained from farmers and secondary data were obtained from various research results and from the local Agency. Primary and secondary data were analyzed descriptively, quantitatively, t-test analysis and economic analysis. Knowing the economic value of beef cattle and corn crop business was analyzed using $\mathrm{R} / \mathrm{C}$ economic analysis. To see whether a beef cattle business and corn crop business was financially feasible or not, it was calculated based on the $R / C$ value. If the value 
of $\mathrm{R} / \mathrm{C}>1$, then the business was said to be feasible, if the value of $\mathrm{R} / \mathrm{C} 1<$ business experienced a loss and if the value of $\mathrm{R} / \mathrm{C}=1$, then the business did not experience profit or loss. Whether the business will be continued or not, depended on the business manager.

Regression analysis to predict the bound variable, $\mathrm{Y}$ if the independent variable, $\mathrm{X}$ was known, which was related to a functional or causal correlation. The independent variable $\mathrm{X}$ was against the variable $\mathrm{Y}$. The results of the field survey analysis on the beef cattle business and the corn crop business. The calculation can be performed using the conversion of farmer's working time in one day counted as 1 Hok, and farmers' working fee were calculated based on the farmer's working area with an average fee between Rp.15,000,-Rp. 20,000, -/day/farmer. So far, farmers have never calculated the expenses for their own labor, so for the number of expenses used for farmers' fee amount to time production inputs that used. Farmer labor costs can be assumed into feed costs, as an indicator of business. As a determinant for the success of beef cattle business and corn crop business with the following formula: (Ashari et al. 2013)

$$
\begin{aligned}
& Y=a+b x \\
& a=\frac{\left(\sum Y-b \sum X\right)}{n} \\
& b=\frac{N \sum X Y-\left(\sum X\right)\left(\sum Y\right)}{N \sum X^{2}-\left(\sum X\right)^{2}}
\end{aligned}
$$

Where:

$\mathrm{Y} \quad=$ Farmers' income (beef and corn)

$\mathrm{X} \quad=$ Independent variable (capital, labor and farmers' working time)

$\mathrm{A}=$ Constant value $\mathrm{Y}$ if $\mathrm{X}=0$

$\mathrm{B}=$ Line value as prediction that indicated increase value $(+)$ or decrease value (-) Y variable

The collected data from this research were then tabulated and processed statistically multiple linear regressions with the mathematical formula as follow:

$\mathrm{Y}=\mathrm{a}_{0}+\mathrm{a}_{1} \mathrm{X}_{1}+\mathrm{a}_{2} \mathrm{X}_{2}+\mathrm{a}_{3} \mathrm{X}_{3}+\mathrm{a}_{4} \mathrm{X}_{4}+\mathrm{a}_{5} \mathrm{X}_{5}+\mathrm{a}_{6} \mathrm{X}_{6}+\varepsilon_{7} X_{7}$

$\mathrm{Y}=$ Technical efficiency effect

$\mathrm{X}_{1} \quad=$ Farmer age

$\mathrm{X}_{2} \quad$ Education

$\mathrm{X}_{3}=$ Number of cows that breed

$\mathrm{X}_{4}=$ Land area that used for corn business

$\mathrm{X}_{5} \quad=$ Farmer experience

$\mathrm{X}_{6} \quad=$ Number of farmer's family member

$\mathrm{X}_{7} \quad=$ Farmer working time

$\mathrm{X}_{8} \quad=$ Error

The combination of beef cattle business and corn crop business in education, farming or livestock experience, farmer working time and number of families was as dependent variable. The number of beef cattle that were breed and the area of land and the number of family members was as an independent variable. The estimated output was analyzed to determine the economic value of several production variables. 
All efforts in any form were of course to obtain optimal benefits (Winarso et al., 2006). The economic value of beef cattle business and food crops business was based on the number of beef cattle sold and the production of corn sold. Gross income and net income were affected by the amount of costs incurred during one year can be calculated using the $\mathrm{R} / \mathrm{C}$ calculation value.

\section{RESULTS AND DISCUSSION \\ General Conditions of Research Area}

The general condition of the Gowa Regency consisted of lowland and highland areas, with an elevation of between 2800 meters above sea level. The Gowa Regency was mostly $72.26 \%$ of the highlands, and constituted the agricultural sector (Central Bureau of Statistics of South Sulawesi Province, 2017). The agricultural commodity data showed the potential for agricultural, livestock and plantation waste to support the development of beef cattle. Farming and plantation waste can be used as alternative feed ingredients for beef cattle. Rice straw production as much as $1,536,471$ tons/year, rice bran as much as 102,432 tons/year, corn cobs as much as 37,418 tons/year, corn straw as much as 456,052 tons/year, soy straw as much as 6,152 tons/year, coconut waste as much as 87,364 tons/year, cacao waste as much as 544,569 tons/year, and palm oil waste as much as 777,007 tons/year (Central Bureau of Statistics of South Sulawesi Province, 2017).

The development of beef cattle in South Sulawesi Province in 2017 was 165,625 cows (Animal Husbandry and Animal Health Statistics 2018). Beef cattle population in Gowa Regency in 2016 was 107,538 cows and in 2017 was 112,915 cows, increased by 24\%/year (Central Bureau of Statistics of South Sulawesi Province, 2017). Beef cattle population both by province and regency/city continued to increase although not very significant. Population and density of beef cattle in each sub-district of South Sulawesi Province with an area of 170,544 ha of harvest lowland rice, which was one of the rice barn areas and corn area of 168,871 ha. The potential of beef cattle was quite big when seen from all the Sub-districts in their efforts to grow food crops. The density of cows per ha from the harvested area can be balanced with the conditions of the land and the number of cows breed by each farmer.

\section{Farmer Characteristics}

The characteristics of farmers in the beef cattle business and corn crop business had in common the number of their own beef cattle and the area of their own agricultural land. Beef cattle in farmers now had started to be developed through breeding and rearing. The productivity of beef cattle owned by farmers was not yet so fast. It caused by capital and business methods were still simple. The types of cows breed by farmers were cows (Bali, PO, Brahman and Limousin) and the way to breed them was shepherded. Whereas, in the food crop business that was mostly cultivated by farmers were rice, corn and secondary crops. Ownership of the number of beef cattle and different land area among farmers did not make a problem for other farmers. According to Rusdiana et al., (2012), in principle no matter how good a beef cattle development program was, if the social aspects, especially farmer income, the program was less profitable, then the program was considered by farmers to be useless. 
This was due to the level of farmers 'income which was one of the main factors for farmers' welfare. Almost all farmers worked on their own agricultural business, and were the closest relatives. The availability of farmers' working time was used to do farming and livestock business (Rusdiana et al., 2018). Farmers' working time can be affected by the area of agricultural land and the number of livestock that breed (Dewi et al., 2007). The estimated of technical inefficiencies in cows and corn business were shown in Table 1

Table 1. Estimating factors in beef cattle and corn crop business in farmers

\begin{tabular}{lccc}
\hline \multicolumn{1}{c}{ Variables } & Coefficient & T-calculate & Pro.Significance \\
\hline Constants & -1.651 & -2.86131 & 0.0000 \\
Farmer age & $-0.3273^{* *}$ & -1.2923 & $0.2122^{* *}$ \\
Farmer education & -0.3262 & -1.2741 & $0.3421^{*}$ \\
Number of cow that breed & $-0.3384^{*}$ & -1.8463 & $0.0000^{* * *}$ \\
Business land area & $-0.4595^{* * *}$ & -1.6255 & 0.000 \\
Farmer experience & -0.2174 & -2.3812 & 0.1256 \\
Number of family members & -0.4756 & -1.5423 & 0.4321 \\
Farmer working time & $0-.3373$ & -1.1923 & 0.9841 \\
Adjusted R-Square & 12.4321 & & \\
F-Sig & 0.0000 & & \\
\hline
\end{tabular}

Source: Primary Data 2018, processed.

Information: *** : significant at $99 \%$ confidence level, ** : significant at $95 \%$ confidence level,

* $\quad$ : significant at $90 \%$ confidence level

Table 1 showed that the results of the t-test analysis of the average similarity at the $99 \%$ confidence level showed real significant between the number of beef cattle and the area of land that planted corn. The significance value (Sig) of 0.000 was smaller than $(\mathrm{P}<0.05)$. The real farmer labor at a level was $99 \%$ and had a positive effect on beef cattle business and corn plant business to the productivity of farmers' family labors. Farmer education had no significant effect on the confidence level of 0.555. The farmers' experience was quite high at $(\mathrm{P}>0.05)$, supported by the age of farmers who were still productive. The results of regressions obtained Y $=\mathrm{X} 10,323+$ $0.083 x 2+0.322+x 3,0,334+x 40,455+x 50,214+x 60,476+x 70,333$. Where, the factors can influence the improvement of farmers' businesses. Meanwhile the experience of farmers from the results of the t-test was evident at the confidence level (>0.05). According to Andriati and Sudana (2007), farmers' formal education or knowledge was still relatively low and did not affect other farming activities, meaning that their willingness, ability to work was higher. Several factors affected farmers' income from corn and beef cattle business in each variable, significantly affected the results of production that produced.

\section{Production Costs and Farmers' Economic Value}

The results of the estimation analysis of the regression coefficient can be found from the independent variable of all production costs in each farmer's business. Production costs in beef cattle business for the cost of purchasing seeds, the cost of making a cage, the cost of cage equipment, the cost of feed, the cost of medicines, labor costs and other costs. According to Hartono (2011), beef cattle business that required a lot of money was used to buy seeds, calculated livestock labors and feed. 
While, for the production costs in the corn crop business, it was the cost of purchasing seeds or seedlings, the cost of cultivating land, the cost of planting, the cost of fertilizing, the cost of cleaning grass, the cost of chemical fertilizers, the cost of manure, spraying costs, post-harvest costs and other costs. The availability of agricultural land showed that beef cattle population was quite high and expected to support the economic activities of farmers.

The capacity support of farmers' resources, surrounding funding potential of land resources in the supply of feed was very sufficient. Therefore, the Gowa Regency region can be developed beef cattle business and agricultural businesses. Then, the beef cattle business in farmers can be directed at the breeding business and rearing business. According to Rohaeni et al., (2006), the effect of increasing the economic value of farmers can be demonstrated through the ability of businesses and how to manage them. The number of beef cattle that were breed and the land area owned by farmers had a significant effect on increasing the economic value of farmers. The number of beef cattle that breed was 3 cows/farmer and an average land area of 0.90-1.0 ha/farmer will be able to increase economic value. The profits obtained by farmers from the sale of calves, females, males, active mother from various ages and corn production. The average and economic value of beef cattle business and corn crop business were shown in Table.2.

Table.2. Average economic value of beef cattle and corn crop business in farmers

\begin{tabular}{lccc}
\hline \multicolumn{1}{c}{ Variable } & Average & $\begin{array}{c}\text { Deviation } \\
\text { Standard }\end{array}$ & $\begin{array}{c}\text { Error } \\
\text { Standard }\end{array}$ \\
\hline I. Beef cattle business results & & & \\
Beef cattle gross profit (Rp Million) & 9.32 & 2,13 & 0.31 \\
Beef cattle net profit (Rp Million) & 4,85 & 2,03 & 0.23 \\
Beef cattle owned (head) & 3.23 & 1.17 & 0.21 \\
Gross income vs Net income (DF=26), t-test & 4.47 & 2,11 & 0.13 \\
value = 4,47 value R/C 1.92 & & & \\
II. Food crop business results (corn) & & & \\
Farming gross profit (Rp million) & 11,64 & 3,78 & 0.34 \\
Farming net profit (Rp million) & 5.88 & 2.36 & 0.35 \\
Land owned (Ha) & 0,83 & 0,07 & 0.02 \\
Gross income vs Net income (DF=26), t-test & 5.76 & 2,02 & 0.21 \\
value = 5,88 value R/C 1.97 & & & \\
\hline Source: Primary Data 2018, processed. & & & \\
\hline
\end{tabular}
Source: Primary Data 2018, processed.

Table. 2, the predictive factor that had positive value was the cost of purchasing seeds and farmer labor, both the beef cattle business and the corn crop business. Net profit from beef cattle business operations was Rp.4.85 million/year, equivalent to Rp.404,166/month with $\mathrm{R} / \mathrm{C}$ of 1.92 . The net profit from corn crop business was Rp.5.88 million/year, equivalent to Rp.404,166/month with R/C of 1.97. This result was shown by the value of t-test as a variable that influenced the significance value $(\mathrm{P}>0.05)$. In terms of production costs, the beef cattle business and the corn crop business were relatively moderate, because the fertilizer that used was from the livestock waste that owned by themselves. Then, feed costs were assumed to be in the labor costs of farmers. Farmers never calculated labor costs, nor did other production costs, because the business was considered self-owned. But in the 
business economy, even the smallest business was still calculated production costs and profits.

The biggest cost was the production cost for the purchase of beef cattle germs, cages and labor. This showed that potential beef cattle and corn crop businesses can support the development of beef cattle populations and increase the economic value of farmers. Indirectly, farmers' economic development increased and welfare increased. The beef cattle and corn crops were the main commodity that many farmers tried in every village. According to Rusdiana et al., (2016) a cow business that was combined with a corn crop business had increased farmer profits. In addition to beef cattle business, corn crop can optimize the land and overcome the risk of land, after the rice harvest, so that crop failure was controlled.

\section{CONCLUSIONS}

Based on the research results, concluded the results of the t-test analysis of the significant average similarity at a 99\% confidence level was significant to the number of beef cattle and land area. The most responsive variable of farmer's labor and had a significant effect on confidence level of 99\%. Significance education was at $95 \%$ confidence level. The experience of farmers was quite high significantly $(\mathrm{P}>$ 0.05). The farmers' net profit of beef cattle business was Rp.4.85 million/year, equivalent to Rp.404,166/month with R/C 1.92. The farmers' net profit of corn in the amount of Rp.5.88 million/year was equivalent to Rp.490,000/month with an $\mathrm{R} / \mathrm{C}$ value of 1.97 . The corn crop and beef cattle farmers received profits at the same time. In terms of economic value in farmers, beef cattle and corn crop business with an $\mathrm{R} / \mathrm{C}$ value $>1$, it can be said that the business was feasible to be maintained).

\section{RECOMMENDATION}

The corn crop and beef cattle business in farmers was quite significant, so the business needed to be maintained. Beef cattle and corn crop business were economically feasible, because farmers gained profits at the same time. Female calf beef cattle can be maintained as a substitute for breed stock when they were infested. Farmers can use corn straw waste as daily feed for beef cattle, so farmers can reduce feed costs. It was expected that the results of this research will be useful as a material for the next policy makers.

\section{REFERENCES}

Andriati dan Wayan Sudana. 2007. Keragaman dan analisis finansial usahatani padi (Kasus Desa Primatani, Kabupaten Karawang, Jawa Barat). Balai Besar Pengkajian dan Pengembangan Teknologi Pertanian

Bogor, Jurnal Pengkajian dan Pengembangan Teknologi Pertanian, 10(2):106118.Anantanyu, S. 2011. Kelembagaan petani: peran dan strategi pengembangan kapasitasnya. Jurnal Sosial Ekonomi Petanian dan Agribisnis, 7(2):102-109.

Ashari, Ening Ariningsih, Yana Supriyatna, Cut Rabiatul Adawiyah dan Sri Suharyono. 2013. Kajian Efektivitas Sistem Resi Gudang Dalam Stabilisasi Pendapatan Petani. Jurnal Kebijakan Pertanian dan Kajian Isu-Isu Aktual 
Kebijakan Pembangunan Pertanian 2013. Pusat Sosial Ekonomi dan Kebijakan Pertanian Badan Penelitian dan Pengembangan Pertanian, Kementerian Pertanian, Desember 2013, hal, 1-115

Andri Kuncoro Boga. 2014. Profil dan karakteristik ekonomi petani tanaman pangan di Bojnegoro. Jurnal Agrekonomika, Universitas Trunojoyo Madura, Studi Agribisnis Fakultas Pertanian, 3(2):166-179

Bamualim. A. 2010. Pengembangan teknlologi pakan sapi potong di dearh semi arid Nusa Tenggara. Orasi Pengukuhan Profesor Riset Bidang Pemuliaan Ruminansia (Pakan dan Nutrisi Ternak). Kemnetrian Pertanian, 29 Nopemebr hal. 1-59.

Badan Pusat Statistik Propinsi Sulawesi Selatan 2017. Perkembangan populasi sapi potong daan produksi limbah hasil pertanian, kehutan dan perkebuanan di setiap Kecamatan, Kabupaten Gowa Propinsi Sulawesi Selata, dalam angka sementara, desember 2018.

Diwyanto, K., Bambang, R.Prawiradiputra dan Darwinsyah. 2002. Integrasi tanaman-ternak dalam pengembangan agribisnis yang berdaya saing berkelanjutan dan berkerakyatan. Wartazoa,12(1):1-8

Demitria.D., Harianto, Sjafri.M., dan Nunung. 2006. Peran Pembangunan Sumberdaya Manusia dalam Peningkatan Pendapatan Rumah Tangga Petani di Daerah Istimewa Yogyakarta. Forum Pascasarjana. IPB. 33(3):155-164.

Dewi. S., Alam dan Haris. 2007. Analisis Titik impas dan sensitivitas terhadap kelayakan finansial usahatni padi sawah. Balai Besar Pengkajian dan Pengembangan Teknologi Pertanian Bogor, Jurnal Pengkajian dan Pengembangan Teknologi Pertanian 10(2): 119-125

Hartono Budi. 2011. Analisis ekonomi rumah tangga peternak sapi potong di Kecmatan DomsolKabupaten Donggala, Provinsi Sulawesi Tengah. Jurnal Ternak Tropika. 12(1):60-70.

Hermawan S. 2012. Dampak sekolah lapang pengelolaan tanaman terpadu terhadap adopsi teknologi, produktivitas dan pendapatan usahatani padi, Jurnal Pengkajian dan Pengembangan Teknologi Pertanian16(2):140-148

Prawiradiputra.B.R. 2009. Masih adakah peluang pengembangan integrasi tanaman dengan ternak di Indonesia. Wartazoa Buletin Ilmu Peternakan Indonesia 19(3):143-155.

Rohaeni.E.S., N.Amali, Sumanto., A.Darmawan dan A.Sabhan. 2006. Pengkajian integrasi usahatani jagung dan ternak sapi di lahan kering Kabupaten Tanah laut, Kalimantan Selatan. Jurnal Pengkajian dan Pengembangan Teknologi Pertanian, 9(2):129-139

Rusdiana S., B. Wibowo dan L. Praharani. 2010. Penyerapan Sumberdaya Manusia Dalam Analisis Fungsi Usaha Penggemukan Sapi Potong Rakyat Di Pedesaan. Prosiding Seminar Nasional Teknologi Peternakan dan Veteriner. Penyunting L.Hardi.P. lily.N., Sofjan.I., Wisri.P., Tati., Nurhayati. Anneke.A., Rini.D., N.L.P. Indi.P., dan Sarwitri.E.Estuningsih. Pusat Penelitian dan Pengembangan Peternakan, 3-4 Agustus 2010. hal. 453-460. 
Rusdiana, S., Rasali, H, Matondang dan Chalid Talib. 2012. Economic analysis of selling pregnant female in bussines of raising pregant beet cattle. Proceeding International Conference on Livestock, Tim Editor, Elizabet, E, E. Martindah, Parsetiyo, H, Praharani.L, and C.Talib. Froductioan and Veterinary Technolgy, Indonesian center Animal research and Development, Bogor Indonesian, October 1-4-2012, hal. 384-395

Rusdiana, S., dan Adawiyah, C.R. 2013. Analisis ekonomi dan prospek usaha tanaman dan ternak dilahan perkebunan kelapa.Jurnal Sosial Ekonomi Pertanian dan Agribisnis, 10(1):118-131.

Rusdiana, S., U., Adiati dan R. Hutasoit. 2016. Analisis ekonomi usaha ternak sapi potong berbasis agroekosistem di Indonesia. Jurnal Sosail Ekonomi dan Kebijakan Pertanan. Jurnal Agroekonomika, 5(2):137-149.

Rusdiana, S. and Soeharsono. 2017. Farmer group performance bali cattle in luwu district east: the economic analysis. The International Joural Of Trovical Veterinery and Biomedical Research, The Faculty of Veterinery Medicine Syiah Kuala University, May 2017, 2(1):18-29.

Rusdiana, S, Soeharsono and Teuku Reza Ferasyi. 2017. Beet catlle busines in dry land area Parangloe Distric Gowa. The International Joural Of Trovical Veterinery and Biomedical Research, The Faculty of Veterinery Medicine Syiah Kuala University, 2(2):11-16.

Rusdiana, S., L. Praharani dan D.A. Kusumaningrum. 2018. Perbaian skala usaha sapi potong pada kelompok peternak Malingping dan Hasanah di Kabupaten Sukabumi. Jurnal Sosial Ekonomi Pertanian 15(1):58-69

Rusdiana, S, E.Sutedi, Umi Adiati dan dan Diana, N. Kusumaningrum 2019. Integrasi usaha tanaman pangan dan sapi potong secara analisis keuntungan pada petani trans,igran di Bengkulu Tengah. Jurnal Vteriner, 20(1):74-86

Sodiq Akhmad, A., Yuwono, P., 2016. Pola pengembangan dan produktivitas sapi potong Program Kemitraan Bina Lingkungan di Kabupaten Banyumas dan Cilacap Propinsi Jawa -Tengah. Jurnal Agripet, 16(1):56-61.

Sodiq Akhmad, Suwarno, Farida Rizki Fauziyah, Yusmi Nur Wakhidati dan Pambudi Yuwono. 2017. Sistem produksi peternakan sapi potong di pedesaan dan strategi pengembangannya, Jurnal Agripet, (17) No.1: 60-66.

Statistik Peternakan dan Kesehatan Hewan 2018. Populasi ternak sapi potong di Indonesia tahun 2013-2017. Direktorat Jenderal Peternakan dan Kesehatan Hewan Kementerian Pertanian RI. Jakarta Desember 2017. Hal 234

Yusdja,Y. dan N, Ilham. 2004. Tinjauan kebijakan pengembangan agribisnis sapi potong. Jurnal Analisis Kebijakan Pertanian 2(2):183-203.

Winarso, B., Rosmiyati, S., dan Chaerul, M. 2006. Tinjauan ekonomi ternak sapi potong di Jawa Timur, Forum Penelitian Agro Ekonomi. Juli 2006, 23(1):61 71. 